\title{
Chemistry claim provokes strong reaction
}

\section{Alison Abbott, Munich}

A bitter dispute between Nobel laureates that has festered behind the scenes for nearly 40 years is now getting a very public airing.

The argument centres on who should get the credit for a set of rules that help to predict the outcome of certain chemical reactions. One of the three chemists involved in the argument is taking the unusual step of publishing his version of events in a leading chemistry journal.

On 19 November, Roald Hoffmann of Cornell University in Ithaca, New York, winner of the 1981 Nobel Prize in Chemistry, put his side of the story online in Angewandte Chemie (R. Hoffmann Angew. Chem. Int. Edn 43, doi:10.1002/anie.200461440;2004).

The catalyst for this move was a claim made in public for the first time by E. J. Corey, a chemist at Harvard University, who won a Nobel in 1990. In an acceptance speech for the American Chemical Society's Priestley medal earlier this year, Corey said that he sowed the seed of the idea that led to Hoffmann's prize. The third chemist involved in the row, Robert Burns Woodward, received his Nobel prize in 1965 but died in 1979.

The story begins in the mid-1960s, when all three chemists were at Harvard. Woodward was working on the synthesis of vitamin $\mathrm{B} 12$, and was trying to find out why the molecular geometry of some reaction products was the opposite of that predicted by theory.

He believed that the answer might lie in quantum-mechanical effects related to the orbits of electrons in organic molecules, and he recruited Hoffmann - a junior fellow with a growing reputation as a talented theorist - to help him develop this idea. Together, they worked out the Woodward-Hoffmann

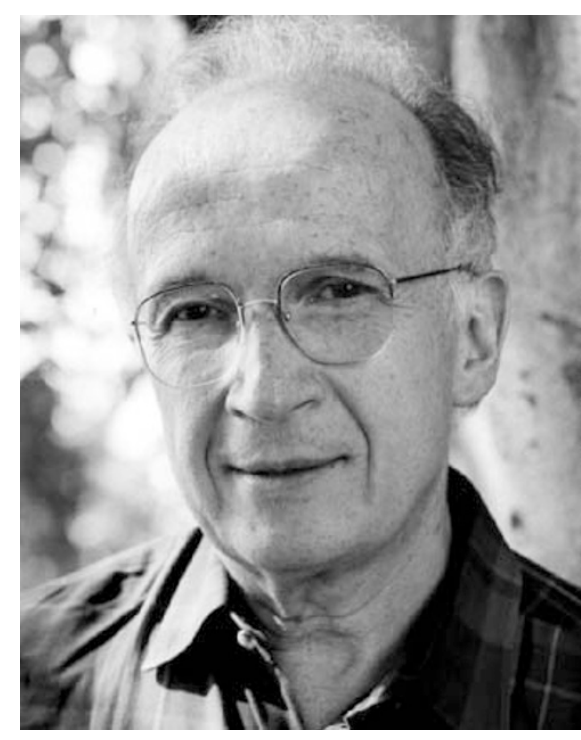

Nobel laureate Roald Hoffmann hopes to settle an argument over rules that bear his name.

rules, which predict the outcome of certain organic reactions based on the orbits of the electrons in the starting materials.

The pair established that the rules applied to a wide class of reactions in organic chemistry, and in doing this helped to revolutionize the field, says Henning Hopf, a synthetic chemist at the Technical University of Braunschweig in Germany.

But Corey, who knew both Woodward and Hoffmann, has now gone public with his claim that he first suggested the idea to Woodward. "On May 4, 1964, I suggested to my colleague R. B. Woodward a simple explanation ... that provided the basis for the further development of these ideas into what became known as the Woodward-Hoffmann rules," he said as part of his acceptance speech for the Priestley medal (Corey, E. J. Chem. Eng. News 82 (13), 42-44; 2004).

Corey had previously told several people, including Hoffmann, that he believed he had seeded the idea that led to the rules - and that he was offended that his input was not acknowledged. But he did not speak about this to Woodward, who received his Nobel for an unrelated idea.

In his article, Hoffmann argues that Corey's claim is "not right". He recalls Corey telling him of the 1964 conversation "sometime in the 1970s" and not taking it seriously. He adds that only days after his Nobel prize announcement in 1981, he received a letter from Corey repeating the claim. Corey asked Hoffmann to mention his contribution in his Nobel speech, which Hoffmann declined to do. "I found it unfair that Corey was asking me to make his claim for him," Hoffmann says. "Especially as Woodward had already died and could not comment."

Corey later told Hoffmann that he hadn't wanted to raise the subject himself because he didn't want to damage Harvard - and because he thought that Woodward would mellow with age and "grow more sensitive to his own conscience”.

Scientists who were in the Corey and Woodward labs at the time say that they are embarrassed by the episode, and puzzled that Corey should reveal his claim after 40 years of silence. "E. J. probably did say something to Woodward about molecular orbital theory, but it was Woodward who picked up the baton and ran with it, with Hoffmann," says Ian Fleming, a chemist at the University of Cambridge, UK, who was a postdoc with Woodward in 1964. Corey declined to comment.

\section{Asian nations build bridges to bolster science}

\section{K. S. Jayaraman, New Delhi}

China and India have signalled a thaw in their previously frosty relations by agreeing to forge closer scientific ties, including plans to work on nuclear energy and space research.

The two countries, whose scientific productivity has mushroomed over the past decade, announced on 17 November that they will set up a Joint Steering Committee, co-chaired by their science ministers, to promote collaboration.

"This is the first time that cooperation in science and technology between the two nations has gone to ministerial level," says Valangiman Ramamurthi, India's science secretary. "Until now, collaboration has consisted of the exchange of scientists and holding workshops.'

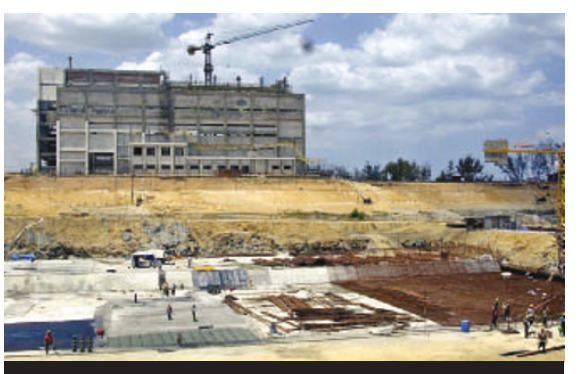

China is to work with India on nuclear projects, such as this reactor being built near Madras.

The committee, which will comprise top officials from government departments, will be decided in the next few weeks. A formal agreement will be signed when Indian science minister Kapil Sibal visits
Beijing early in 2005, Ramamurthi says.

The decision to create the committee capped a week-long tour of Indian scientific institutions by a 30-strong Chinese delegation led by state councillor Chen Zhili. The fact that Chen is the first Chinese minister to visit India is a measure of how seriously China views the collaboration, Indian officials say. The delegation was particularly keen to collaborate on biotechnology, space science, nuclear technology, oceanography and research in herbal medicines, says Sibal.

Ramamurthi adds that many things can be done jointly. Combining Chinese strength in electronic hardware with India's skills in software could, for example, make the pair a formidable force in the global information-technology market, he says. 